\section{JURNAL EKONOMI EFEKTIF}

ISSN : $2622-8882$, E-ISSN : 2622-9935

Jurnal Ekonomi Efektif, Vol. 4, No. 1, Oktober 2021 @Prodi Manajemen Fakultas Ekonomi Universitas Pamulang

\title{
PENGARUH MOTIVASI KERJA DAN LINGKUNGAN KERJA TERHADAP KINERJA KARYAWAN PADA PT SRIWIJAYA DINAMIKA PERKASA DI SURABAYA
}

\author{
Mulyadi $^{1 *}$, Niko Purnomo², Sutrisno $^{3}$, Komarudin $^{4}$, N. Lilis Suryani ${ }^{5}$ \\ Universitas Pamulang, Tangerang Selatan, Banten, Indonesia \\ dosen00031@unpam.ac.id*
}

Manuskrip: Agustus -2021; Ditinjau: Agustus -2021; Diterima: September-2021; Online: Oktober-2021; Diterbitkan: Oktober-2021

\begin{abstract}
ABSTRAK
Penelitian ini bertujuan untuk mengetahui pengaruh motivasi kerja dan lingkungan kerja terhadap kinerja karyawan pada PT. Sriwijaya Dinamika Perkasa di Surabaya. Metode yang digunakan adalah explanatory research dengan teknik analisis menggunakan analisis statistik dengan pengujian regresi, korelasi, determinasi dan uji hipotesis. Hasil penelitian ini motivasi kerja berpengaruh signifikan terhadap kinerja karyawan sebesar 46,7\%, uji hipotesis diperoleh $\mathrm{t}$ hitung $>\mathrm{t}$ tabel atau $(7,190>2,001)$. Lingkungan kerja berpengaruh signifikan terhadap kinerja karyawan sebesar 48,8\%, uji hipotesis diperoleh t hitung > t tabel atau $(7,492>2,001)$. Motivasi kerja dan lingkungan kerja secara simultan berpengaruh signifikan terhadap kinerja karyawan dengan persamaan regresi $\mathrm{Y}=7,031+0,378 \mathrm{X} 1+0,466 \mathrm{X} 2$ dan kontribusi pengaruh sebesar 65,2\%, uji hipotesis diperoleh $\mathrm{F}$ hitung $>\mathrm{F}$ tabel atau $(54,241>2,760)$.
\end{abstract}

Kata Kunci: Motivasi Kerja, Lingkungan Kerja, Kinerja Karyawan

\section{ABSTRACT}

This study aims to determine the effect of work motivation and work environment on employee performance at PT. Sriwijaya Dynamics Perkasa in Surabaya. The method used is explanatory research with analytical techniques using statistical analysis with regression, correlation, determination and hypothesis testing. The results of this study that work motivation has a significant effect on employee performance by 46.7\%, hypothesis testing is obtained $t$ count > t table or $(7.190>2.001)$. The work environment has a significant effect on employee performance by $48.8 \%$, hypothesis testing is obtained $t$ count $>t$ table or $(7.492>2.001)$. Work motivation and work environment simultaneously have a significant effect on employee performance with the regression equation $Y=7.031+0.378 X 1+0.466 X 2$ and the contribution of the effect is $65.2 \%$, hypothesis testing is obtained $F$ count $>F$ table or $(54.241$ $>2.760)$.

Keywords: Work Motivation, Work Environment, Employee Performance 


\section{PENDAHULUAN}

\section{A. Latar Belakang Masalah}

Peranan Sumber Daya Manusia dalam suatu organisasi sangat penting mengingat komponen tersebut dapat menentukan tingkat keberhasilan perusahaan. Pengelolaan manajeman bisnis yang profesional dan sumber daya manusia yang berkualitas sangat diperlukan perusahaan demi tercapainya tujuan utama perusahaan tersebut. Disisi lain, faktor lingkungan kerja yang kondusif juga turut mendukung tingkat kualitas kinerja karyawan yang baik bagi perusahaan.

PT. Sriwijaya Dinamika Perkasa Surabaya berdiri pada tahun 2006 yang berawal terbentuk dari pemikiran untuk memudahkan wisatawan yang berwisata ke kota Surabaya dapat mudah mengunjungi tempat wisata yang ada di kota surabaya. Pada akhirnya membuka usaha penyewaan kendaraan mobil kecil-kecilan dengan memiliki 5 kendaraan mobil toyota avanza, namun sampai saat ini PT. Sriwijaya Dinamika Perkasa Surabaya menjadi perusahaan besar dengan mempunyai segala armada kendaraan dari mobil mewah, mini bus, dan bus pariwisata.

Kinerja merupakan hasil kerja secara kualitas dan kuantitas yang dicapai oleh seorang pegawai dalam melaksanakan tugasnya sesuai dengan tanggung jawab yang diberikan kepadanya. Dari kinerja ini dapat dinilai apakah kinerja pegawai tersebut dapat diklasifikasikan ke dalam hasil yang berkualitas atau sebaliknya (Mangkunegara, 2018:45).

Faktor yang dapat mempengaruhi kinerja karyawan adalah motivasi kerja. Menurut Hasibuan (2018:65) motivasi kerja adalah pemberian daya penggerak yang menciptkan kegairahan kerja seseorang agar mereka mau bekerja sama, bekerja efektif, dan terintegrasi dengan segala daya upayanya untuk mencapai kepuasan.

Fenomena yang terjadi pada PT. Sriwijaya Dinamika Perkasa Surabaya adalah motivasi kerja karyawan. Berikut Tabel 1.1 yang akan menjelaskan unsur penilaian motivasi kerja pada karyawan PT. Sriwijaya Dinamika Perkasa Surabaya, sebagai berikut:

Tabel 1. Data Penilaian Motivasi Kerja PT. Sriwijaya Dinamika Perkasa Surabaya Tahun 2020

\begin{tabular}{|c|l|c|c|c|c|}
\hline No & Unsur Penilaian Motivasi & Jumlah Karyawan & Target & Nilai & Pencapaian \\
\hline 1 & Tatangan Pekerjaan & 61 & $100 \%$ & $65 \%$ & Cukup \\
\hline 2 & Tanggung jawab pekerjaan & 61 & $100 \%$ & $60 \%$ & Kurang \\
\hline 3 & Prestasi Kerja & 61 & $100 \%$ & $55 \%$ & Kurang \\
\hline 4 & Kesejahteraan & 61 & $100 \%$ & $55 \%$ & Kurang \\
\hline 5 & Jabatan & 61 & $100 \%$ & $45 \%$ & Buruk \\
\hline 6 & Hubungan kerja & 61 & $100 \%$ & $55 \%$ & Kurang \\
\hline 7 & Harapan & 61 & $100 \%$ & $55 \%$ & Kurang \\
\hline 8 & Penghargaan & 61 & $100 \%$ & $50 \%$ & Buruk \\
\hline \multicolumn{2}{|l|}{ Rata-Rata Pencapaian } & & $55 \%$ & Kurang \\
\hline
\end{tabular}

Sumber: Data Internal PT. Sriwijaya Dinamika Perkasa Surabaya, 2021

Berdasarkan tabel di atas, unsur penilaian motivasi kerja karyawan yang memperoleh nilai terendah pada penilaian motivasi kerja karyawan terhadap jabatan yang mendapatkan nilai 45\%. Dapat diartikan bahwa para karyawan pada PT. Sriwijaya Dinamika Perkasa Surabaya merasa kurang termotivasi untuk memperoleh hasil promosi jabatan, dikarenakan pemilik perusahaan ini tidak pernah mengadakan gelar promosi jabatan untuk para karyawannya yang berprestasi. Sehingga, para karyawannya merasa pencapaian yang sudah diperoleh tidak dihargai oleh perusahaan, karena tidak adanya timbal balik yang diberikan dari perusahaan.

Selain motivasi adalah lingkungan kerja yang merupakan faktor penting karena setiap elemen pasti akan merasakan situasi lingkungan, baik secara langsung ataupun 
tidak langsung terhadap kegiatan yang berhubungan pada satu kondisi yang tidak dapat dinilai secara akurat dan diprediksi.

Adapun fenomena lain di PT. Sriwijaya Dinamika Perkasa Surabaya adalah lingkungan kerja. Berikut Tabel 2 yang akan menjelaskan lingkungan kerja di PT. Sriwijaya Dinamika Perkasa Surabaya, dan pra survey ini dibagikan kepada 20 karyawan sebagai berikut:

Tabel 2. Data Pra Survei Lingkungan Kerja PT. Sriwijaya Dinamika Perkasa Surabaya

\begin{tabular}{|c|l|c|c|}
\hline No & \multicolumn{1}{|c|}{ Pernyataan } & Iya & Tidak \\
\hline 1 & Perlengkapan penerangan lampu dalam ruangan saya sudah memadai & 15 & 5 \\
\hline 2 & $\begin{array}{l}\text { Suhu udara diruangan ini membuat saya merasa nyaman untuk aktif } \\
\text { bekerja }\end{array}$ & 13 & 7 \\
\hline 3 & $\begin{array}{l}\text { Sirkulasi udara didalam perusahaan sudah sesuai dengan standar } \\
\text { kesehatan dan lingkungan }\end{array}$ & $\begin{array}{l}\text { Kebisingan suara ditempat ini membuat saya merasa nyaman untuk } \\
\text { aktif bekerja, dikarenakan lokasi perusahaan yang berada tepat didekat } \\
\text { daerah pabrik }\end{array}$ & 10 \\
\hline 5 & $\begin{array}{l}\text { Saya mendapatkan jaminan keamanan dalam bekerja baik didalam } \\
\text { maupun diluar lingkungan kerja }\end{array}$ & 5 & 10 \\
\hline
\end{tabular}

Sumber: Data Internal PT. Sriwijaya Dinamika Perkasa Surabaya, 2021

Berdasarkan tabel di atas, menunjukkan bahwa dari beberapa aspek baik perlengkapan, kondisi ruangan, kenyamanan dalam melaksanakan pekerjaan maupun jaminan asuransi menunjukkan masih ada persoalan yang harus diperhatikan oleh perusahaan. Permasalahan yang terjadi pada lingkungan kerja adalah jaminan kemananan yang masih minim, sehingga para karyawan merasa lingkungan kerja di PT. Sriwijaya Dinamika Perkasa Surabaya kurang aman, dikarenakan sering terjadinya kehilangan barang yang dimiliki oleh karyawan. Akibat dari sering terjadinya kehilangan barang, para karyawan merasa tidak nyaman dalam mengerjakan pekerjaannya, dan akhirnya membawa dampak kepada kinerja karyawan.

Berikut data penilaian kinerja karyawan pada PT. Sriwijaya Dinamika Perkasa Surabaya dari tahun 2018-2020 pada tabel 3 dibawah ini:

Tabel 3. Data Penilaian Kinerja PT. Sriwijaya Dinamika Perkasa Surabaya

Tahun 2018-2020

\begin{tabular}{|c|c|c|c|c|c|c|c|c|}
\hline \multirow[b]{2}{*}{ No } & \multirow[b]{2}{*}{ Unsur yang dinilai } & \multirow[b]{2}{*}{$\begin{array}{c}\text { Target } \\
(\%)\end{array}$} & \multicolumn{2}{|c|}{2018} & \multicolumn{2}{|c|}{2019} & \multicolumn{2}{|c|}{2020} \\
\hline & & & Nilai & $\begin{array}{l}\text { Skor } \\
(\%)\end{array}$ & Nilai & $\begin{array}{l}\text { Skor } \\
(\%)\end{array}$ & Nilai & $\begin{array}{l}\text { Skor } \\
(\%)\end{array}$ \\
\hline 1 & $\begin{array}{l}\text { Penugasan keterampilan } \\
\text { bidang tugas }\end{array}$ & 100 & 70 & 7 & 70 & 7 & 65 & 6,5 \\
\hline 2 & Kejujuran & 100 & 80 & 8 & 70 & 7 & 65 & 6,5 \\
\hline 3 & $\begin{array}{l}\text { Kemampuan menerima } \\
\text { tugas }\end{array}$ & 100 & 65 & 6,5 & 65 & 6,5 & 70 & 7 \\
\hline 4 & $\begin{array}{l}\text { Kemampuan kerjasama } \\
\text { tim }\end{array}$ & 100 & 70 & 7 & 65 & 6,5 & 70 & 7 \\
\hline 5 & $\begin{array}{l}\text { Kemampuan bekerja } \\
\text { dengan kualitas dan } \\
\text { kuantitas }\end{array}$ & 100 & 80 & 8 & 70 & 7 & 65 & 6,5 \\
\hline 6 & Semangat kerja & 100 & 70 & 7 & 70 & 7 & 65 & 6,5 \\
\hline 7 & $\begin{array}{l}\text { Ketaatan terhadap } \\
\text { peraturan }\end{array}$ & 100 & 70 & 7 & 70 & 7 & 70 & 7 \\
\hline 8 & Menjaga citra perusahaan & 100 & 70 & 7 & 65 & 6,5 & 65 & 6,5 \\
\hline 9 & $\begin{array}{l}\text { Tanggung jawab terhadap } \\
\text { tugas }\end{array}$ & 100 & 75 & 7,5 & 70 & 7 & 70 & 7 \\
\hline 10 & Penampilan & 100 & 75 & 7,5 & 70 & 7 & 60 & 6 \\
\hline & Total rata rat & & & 72,5 & & 68,5 & & 66,5 \\
\hline
\end{tabular}

Sumber: Data Internal PT. Sriwijaya Dinamika Perkasa Surabaya, 2021 
Dari di atas, dapat di lihat bahwa penilaian kinerja setiap tahun nya menargetkan hasil rata-rata $100 \%$, namun setiap tahunnya mengalami penurunan sehingga pada tahun 2020 mendapatkan nilai rata-rata yang terendah hanya mencapai $66,5 \%$ dari target $100 \%$.

Dari fenomena-fenomena yang sudah dijelaskan tentang beberapa faktor yang mempengaruhi kinerja karyawan, sebelumnya peneliti telah melakukan pra survei fenomena pada 20 orang karyawan PT. Sriwijaya Dinamika Perkasa Surabaya dan telah diperoleh hasilnya, sehingga dari pra survey fenomena ini peneliti dapat menentukan judul skripsi yang akan dijadikan objek penelitian.

Fenomena yang pertama, pada motivasi kerja yang mengindikasikan tentang para karyawan yang kurang bersemangat dalam menjalankan pekerjaannya sehingga menjadi kurang produktif, dapat terlihat dari beberapa karyawan yang mengeluhkan tidak adanya promosi jabatan yang diberikan perusahaan terhadap para karyawan yang berprestasi. Fenomena yang kedua, pada lingkungan kerja yang mengindikasikan tentang kenyamanan para karyawan dengan lingkungan tempat bekerjanya. Para karyawan merasa kalau lingkungan tempat bekerjanya kurang aman, karena adanya beberapa kasus kehilangan yang pernah terjadi ditempat kerja. Fenomena yang ketiga, pada kinerja karyawan yang mengindikasikan tentang para karyawan merasa pekerjaan yang dilakukan sudah secara maksimal, namun masih kurang mewujudkan keberhasilan tujuan dan sasaran yang ditetapkan oleh perusahaan.

Dari fenomena yang terjadi pada karyawan PT. Sriwijaya Dinamika Perkasa Surabaya maka perlu menjadi perhatian karena apabila motivasi kerja, dan lingkungan kerja rendah, akan berpengaruh pada kinerja karyawan sehingga sulit untuk mencapai tujuan perusahaan dalam upaya menciptakan kinerja karyawan yang baik dan optimal.

Penentuan PT. Sriwijaya Dinamika Perkasa Surabaya sebagai obyek penelitian dianggap tepat. Karena penentuan obyek penelitian telah memenuhi unsur permasalahan yang layak untuk diteliti. Penelitian ini mengidentifikasi permasalahan yang tengah dihadapi dan perlu secara cepat dituntaskan oleh PT. Sriwijaya Dinamika Perkasa Surabaya.

Berdasarkan dari kajian kajian peneliti terdahulu, Maka dalam hal ini penulis tertarik mengambil judul "Pengaruh Motivasi Kerja Dan Lingkungan Kerja Terhadap Kinerja Karyawan Pada PT. Sriwijaya Dinamika Perkasa di Surabaya".

\section{B. Rumusan Masalah}

1. Adakah pengaruh antara motivasi kerja terhadap kinerja karyawan pada PT. Sriwijaya Dinamika Perkasa di Surabaya?

2. Adakah pengaruh antara lingkungan kerja terhadap kinerja karyawan pada PT. Sriwijaya Dinamika Perkasa di Surabaya?

3. Adakah pengaruh secara simultan antara motivasi kerja dan lingkungan kerja terhadap kinerja karyawan pada PT. Sriwijaya Dinamika Perkasa di Surabaya?

\section{Tujuan Penelitian}

1. Untuk mengetahui pengaruh antara motivasi kerja terhadap kinerja karyawan pada PT. Sriwijaya Dinamika Perkasa di Surabaya.

2. Untuk mengetahui pengaruh antara lingkungan kerja terhadap kinerja karyawan pada PT. Sriwijaya Dinamika Perkasa di Surabaya.

3. Untuk mengetahui pengaruh secara simultan antara motivasi kerja dan lingkungan kerja terhadap kinerja karyawan pada PT. Sriwijaya Dinamika Perkasa di Surabaya. 


\section{TINJAUAN PUSTAKA}

\section{Motivasi kerja}

Menurut Sutrisno (2019:55), menyatakan bahwa motivasi kerja adalah pemberian daya penggerak yang menciptakan kegairahan kerja seseorang, agar mereka mau bekerja sama, bekerja efektif dan terintegrasi dengan segala upayanya untuk mencapai kepuasan dalam bekerja. Adapun indikator yang digunakan meliputi: Kebutuhan fisiologis, Kebutuhan rasa aman, Kebutuhan sosial, Kebutuhan sosial, Kebutuhan penghargaan, Kebutuhan aktualisasi diri.

\section{Lingkungan Kerja}

Lingkungan kerja adalah keseluruhan alat perkakas dan bahan yang dihadapi, lingkungan sekitarnya dimana seseorang bekerja, metode kerjanya serta pengaturan kerjanya baik sebagai perseorangan maupun kelompok. Sedarmayanti (2020:21). Adapun indikator yang digunakan meliputi: Penerangan, rirkulasi udara, tata letak ruang kerja, privasi ruang kerja, suara bising, penggunaan warna, peralatan kantor, keamanan kerja, musik di tempat kerja.

\section{Kinerja Karyawan}

Menurut Mangkunegara (2019:75) pengertian kinerja adalah hasil kerja secara kualitas dan kuantitas yang dicapai oleh seorang dalam melaksanakan tugasnya sesuai dengan tanggung jawab yang diberikan kepadanya. Adapun indikator yang digunakan sebagai berikut: kualitas kerja, kuntitas kerja, pengetahuan kerja, pelaksanaan tugas, tanggung jawab

\section{METODE PENELITIAN}

\section{Populasi}

Populasi dalam penelitian ini berjumlah 61 responden PT. Sriwijaya Dinamika Perkasa di Surabaya

\section{Sampel}

Sampel dalam penelitian ini berjumlah 61 responden.

\section{Jenis Penelitian}

Jenis penelitian yang dipakai adalah asosiatif, dimana tujuannya adalah untuk mengetahui pengaruh antara variabel bebas terhadap variabel terikat baik parsial maupun simultan

\section{Metode Analisis Data}

Dalam menganalisis data digunakan uji instrumen, uji asumsi klasik, regresi, koefisien determinasi dan uji hipotesis.

\section{HASIL PENELITIAN}

\section{Analisis Deskriptif}

Pada pengujian ini digunakan untuk mengetahui skor minimum dan maksimum, mean score dan standar deviasi dari masing-masing variabel. Adapun hasilnya sebagai berikut:

\begin{tabular}{|c|c|c|c|c|c|}
\hline \multicolumn{6}{|c|}{$\begin{array}{c}\text { Tabel 4. Hasil Analisis Descriptive Statistics } \\
\text { Descriptive Statistics }\end{array}$} \\
\hline & $\mathrm{N}$ & Minimum & Maximum & Mean & Std. Deviation \\
\hline Motivasi Kerja (X1) & 61 & 29 & 47 & 37.15 & 4.343 \\
\hline Lingkungan Kerja (X2) & 61 & 28 & 45 & 37.00 & 3.737 \\
\hline Kinerja Karyawan (Y) & 61 & 31 & 47 & 38.31 & 3.590 \\
\hline Valid N (listwise) & 61 & & & & \\
\hline
\end{tabular}


Motivasi kerja diperoleh varians minimum sebesar 29 dan varians maximum 47 dengan mean score sebesar 3,71 dengan standar deviasi 4,343.

Lingkungan kerja diperoleh varians minimum sebesar 28 dan varians maximum 45 dengan mean score sebesar 3,70 dengan standar deviasi 3,737.

Kinerja karyawan diperoleh varians minimum sebesar 31 dan varians maximum 47 dengan mean score sebesar 3,83 dengan standar deviasi 3,590.

\section{Analisis Kuantitatif}

Pada analisis ini dimaksudkan untuk mengetahui pengaruh variabel independen terhadap variabel dependen. Adapun hasil pengujian sebagai berikut:

\section{a. Analisis Regresi Linier Berganda}

Uji regresi ini dimaksudkan untuk mengetahui perubahan variabel dependen jika variabel independen mengalami perubahan. Adapun hasil pengujiannya sebagai berikut:

\begin{tabular}{|c|c|c|c|c|c|}
\hline \multirow[b]{3}{*}{ Model } & \multicolumn{2}{|c|}{ Coefficients $^{a}$} & \multirow{3}{*}{$\begin{array}{c}\text { Standardized } \\
\text { Coefficients } \\
\text { Beta }\end{array}$} & \multirow[b]{3}{*}{$\mathrm{t}$} & \multirow[b]{3}{*}{ Sig. } \\
\hline & \multicolumn{2}{|c|}{$\begin{array}{l}\text { Unstandardized } \\
\text { Coefficients }\end{array}$} & & & \\
\hline & $\mathrm{B}$ & Std. Error & & & \\
\hline $1 \quad$ (Constant) & 7.013 & 3.033 & & 2.312 & .024 \\
\hline Motivasi Kerja (X1) & .378 & .072 & .458 & 5.227 & .000 \\
\hline Lingkungan Kerja (X2) & .466 & .084 & .485 & 5.544 & .000 \\
\hline
\end{tabular}

a. Dependent Variable: Kinerja Karyawan (Y)

Berdasarkan hasil pengujian pada tabel di atas, diperoleh persamaan regresi $Y$ $=7,031+0,378 X 1+0,466 X 2$. Dari persamaan tersebut dijelaskan sebagai berikut:

1) Konstanta sebesar 7,031 diartikan jika motivasi kerja dan lingkungan kerja tidak ada, maka telah terdapat nilai kinerja karyawan sebesar 7,031 point.

2) Koefisien regresi motivasi kerja sebesar 0,378 , angka ini positif artinya setiap ada peningkatan motivasi kerja sebesar 0,378 maka kinerja karyawan juga akan mengalami peningkatan sebesar 0,378 point.

3) Koefisien regresi lingkungan kerja sebesar 0,466, angka ini positif artinya setiap ada peningkatan lingkungan kerja sebesar 0,466 maka kinerja karyawan juga akan mengalami peningkatan sebesar 0,466 point.

\section{b. Analisis Koefisien Korelasi}

Analisis koefisien korelasi dimaksudkan untuk mengetahui tingkt kekuatan hubungan dari variabel independen terhadap variabel dependen baik secara parsial maupun simultan. Adapun hasil pengujian sebagai berikut:

Tabel 6. Hasil Pengujian Koefisien Korelasi Motivasi kerja Terhadap Kinerja

\section{Karyawan.}

Correlations $^{\mathbf{b}}$

Motivasi Kerja (X1) Kinerja Karyawan (Y)

\begin{tabular}{llrr}
\hline Motivasi Kerja (X1) & Pearson Correlation & 1 & $.683^{* *}$ \\
\cline { 2 - 4 } & Sig. (2-tailed) & & .000 \\
\hline Kinerja Karyawan (Y) & Pearson Correlation & $.683^{* *}$ & 1 \\
\cline { 2 - 4 } & Sig. (2-tailed) & .000 & \\
\hline
\end{tabular}

**. Correlation is significant at the 0.01 level (2-tailed).

b. Listwise $\mathrm{N}=61$

Berdasarkan hasil pengujian diperoleh nilai korelasi sebesar 0,683 artinya motivasi kerja memiliki hubungan yang kuat terhadap kinerja karyawan. 
Tabel 7. Hasil Pengujian Koefisien Korelasi Lingkungan kerja Terhadap Kinerja

Karyawan.

Correlations $^{\text {b }}$

\begin{tabular}{|c|c|c|c|}
\hline & & Lingkungan Kerja (X2) & Kinerja Karyawan $(\mathrm{Y})$ \\
\hline \multirow{2}{*}{$\begin{array}{l}\text { Lingkungan Kerja } \\
\text { (X2) }\end{array}$} & Pearson Correlation & 1 & $.698^{* * *}$ \\
\hline & Sig. (2-tailed) & & .000 \\
\hline \multirow[t]{2}{*}{ Kinerja Karyawan (Y) } & Pearson Correlation & $.698^{* *}$ & 1 \\
\hline & Sig. (2-tailed) & .000 & \\
\hline
\end{tabular}

**. Correlation is significant at the 0.01 level (2-tailed).

b. Listwise $\mathrm{N}=61$

Berdasarkan hasil pengujian diperoleh nilai korelasi sebesar 0,698 artinya lingkungan kerja memiliki hubungan yang kuat terhadap kinerja karyawan.

Tabel 8. Hasil Pengujian Koefisien Korelasi Motivasi kerja dan Lingkungan kerja secara simultan Terhadap Kinerja Karyawan.

Model Summary

\begin{tabular}{|c|c|c|c|c|}
\hline Model & $\mathrm{R}$ & R Square & $\begin{array}{l}\text { Adjusted R } \\
\text { Square }\end{array}$ & Std. Error of the Estimate \\
\hline 1 & $.807^{\mathrm{a}}$ & .652 & .640 & 2.155 \\
\hline
\end{tabular}

a. Predictors: (Constant), Lingkungan Kerja (X2), Motivasi Kerja (X1)

Berdasarkan hasil pengujian diperoleh nilai korelasi sebesar 0,807 artinya motivasi kerja dan lingkungan kerja secara simultan memiliki hubungan yang sangat kuat terhadap kinerja karyawan.

\section{c. Analisis Koefisien Determinasi}

Analisis koefisien determinasi dimaksudkan untuk mengetahui besarnya persentase pengaruh dari variabel independen terhadap variabel dependen baik secara parsial maupun simultan. Adapun hasil pengujian sebagai berikut:

Tabel 9. Hasil Pengujian Koefisien Determinasi Motivasi kerja Terhadap Kinerja

Karyawan.

Model Summary

\begin{tabular}{lr|r|r|r} 
Model & R & \multicolumn{2}{|c|}{$\begin{array}{c}\text { Adjusted R } \\
\text { Square }\end{array}$} & Std. Error of the Estimate \\
\hline 1 & $.683^{\mathrm{a}}$ & .467 & .458 & 2.643 \\
\hline
\end{tabular}

a. Predictors: (Constant), Motivasi Kerja (X1)

Berdasarkan hasil pengujian diperoleh nilai determinasi sebesar 0,467 artinya motivasi kerja memiliki kontribusi pengaruh sebesar $46,7 \%$ terhadap kinerja karyawan.

Tabel 10. Hasil Pengujian Koefisien Determinasi Lingkungan kerja Terhadap Kinerja Karyawan.

Model Summary

\begin{tabular}{lrr|rr|r} 
& & \multicolumn{2}{|c|}{} & \\
Model & R & R Square & Adjusted R & Square & Std. Error of the Estimate \\
\hline 1 & $.698^{\mathrm{a}}$ & .488 & .479 & 2.591 \\
\hline
\end{tabular}

a. Predictors: (Constant), Lingkungan Kerja (X2)

Berdasarkan hasil pengujian diperoleh nilai determinasi sebesar 0,488 artinya lingkungan kerja memiliki kontribusi pengaruh sebesar 48,8\% terhadap kinerja karyawan.

Tabel 11. Hasil Pengujian Koefisien Determinasi Motivasi kerja dan Lingkungan kerja Terhadap Kinerja Karyawan.

Model Summary

\begin{tabular}{|c|c|c|c|c|}
\hline Model & $\mathrm{R}$ & R Square & Adjusted R Square & Std. Error of the Estimate \\
\hline 1 & $.807^{\mathrm{a}}$ & .652 & .640 & 2.155 \\
\hline
\end{tabular}


Berdasarkan hasil pengujian diperoleh nilai determinasi sebesar 0,652 artinya motivasi kerja dan lingkungan kerja secara simultan memiliki kontribusi pengaruh sebesar 65,2\% terhadap kinerja karyawan, sedangkan sisanya sebesar 34,8\% dipengaruhi faktor lain.

\section{d. Uji Hipotesis}

\section{Uji hipotesis Parsial (Uji t)}

Pengujian hipotesis dengan uji t digunakan untuk mengetahui hipotesis parsial mana yang diterima.

Hipotesis pertama: Terdapat pengaruh yang signifikan antara motivasi kerja terhadap kinerja karyawan.

Tabel 12. Hasil Uji Hipotesis Motivasi kerja Terhadap Kinerja Karyawan.

\section{Coefficients $^{\mathrm{a}}$}

Unstandardized

Coefficients

\begin{tabular}{|c|c|c|c|c|c|c|}
\hline \multirow{2}{*}{\multicolumn{2}{|c|}{ Model }} & \multicolumn{2}{|c|}{ Coettıcients } & \multirow{2}{*}{$\begin{array}{c}\text { Coefficients } \\
\text { Beta }\end{array}$} & \multirow[b]{2}{*}{$\mathrm{t}$} & \multirow[b]{2}{*}{ Sig. } \\
\hline & & $\mathrm{B}$ & Std. Error & & & \\
\hline 1 & (Constant) & 17.330 & 2.938 & & 5.899 & .000 \\
\hline & Motivasi Kerja (X1) & .565 & .079 & .683 & 7.190 & .000 \\
\hline
\end{tabular}

a. Dependent Variable: Kinerja Karyawan (Y)

Berdasarkan hasil pengujian pada tabel di atas, diperoleh nilai t hitung $>\mathrm{t}$ tabel atau $(7,190>2,001)$, dengan demikian hipotesis pertama yang diajukan bahwa terdapat pengaruh yang signifikan atara motivasi kerja terhadap kinerja karyawan diterima.

Tabel 13. Hasil Uji Hipotesis Lingkungan kerja Terhadap Kinerja Karyawan. Coefficients $^{\mathbf{a}}$

Unstandardized

Coefficients

\begin{tabular}{|c|c|c|c|c|c|c|}
\hline \multicolumn{2}{|c|}{ Model } & $\mathrm{B}$ & Std. Error & Beta & $\mathrm{t}$ & Sig. \\
\hline \multirow[t]{2}{*}{1} & (Constant) & 13.498 & 3.329 & & 4.055 & .000 \\
\hline & Lingkungan Kerja (X2) & .671 & .090 & .698 & 7.492 & .000 \\
\hline
\end{tabular}

a. Dependent Variable: Kinerja Karyawan (Y)

Berdasarkan hasil pengujian pada tabel di atas, diperoleh nilai t hitung $>\mathrm{t}$ tabel atau $(7,492>2,001)$, dengan demikian hipotesis kedua yang diajukan bahwa terdapat pengaruh yang signifikan atara lingkungan kerja terhadap kinerja karyawan diterima.

\section{Uji Hipotesis Simultan (Uji F)}

Pengujian hipotesis dengan uji $\mathrm{F}$ digunakan untuk mengetahui hipotesis simultan yang mana yang diterima.

Hipotesis ketiga Terdapat pengaruh yang signifikan antara motivasi kerja dan lingkungan kerja terhadap kinerja karyawan.

Tabel 14. Hasil Uji Hipotesis Motivasi kerja dan Lingkungan kerja Terhadap

\section{Kinerja Karyawan.}

\section{ANOVA $^{\mathrm{a}}$}

\begin{tabular}{llr|r|r|r|r}
\multicolumn{1}{l}{ Model } & Sum of Squares & \multicolumn{1}{c}{ df } & Mean Square & \multicolumn{1}{c}{ F } & Sig. \\
\hline $1 \quad$ Regression & 503.752 & 2 & 251.876 & 54.241 & $.000^{\mathrm{b}}$ \\
\cline { 2 - 7 } & Residual & 269.330 & 58 & 4.644 & & \\
\hline \multicolumn{1}{l}{ Total } & 773.082 & 60 & & & \\
\hline
\end{tabular}

a. Dependent Variable: Kinerja Karyawan (Y)

b. Predictors: (Constant), Lingkungan Kerja (X2), Motivasi Kerja (X1)

Berdasarkan hasil pengujian pada tabel di atas, diperoleh nilai $\mathrm{F}$ hitung $>\mathrm{F}$ tabel atau $(54,241>2,760)$, dengan demikian hipotesis ketiga yang diajukan bahwa 
terdapat pengaruh yang signifikan atara motivasi kerja dan lingkungan kerja terhadap kinerja karyawan diterima.

\section{Pembahasan Hasil Penelitian}

\section{Pengaruh Motivasi kerja Terhadap Kinerja Karyawan}

Motivasi kerja berpengaruh signifikan terhadap kinerja karyawan dengan korelasi sebesar 0,683 atau memiliki hubungan yang kuat dengan kontribusi pengaruh sebesar $46,7 \%$. Pengujian hipotesis diperoleh nilai t hitung $>\mathrm{t}$ tabel atau $(7,190>2,001)$. Dengan demikian hipotesis pertama yang diajukan bahwa terdapat berpengaruh signifikan antara motivasi kerja terhadap kinerja karyawan diterima.

\section{Pengaruh Lingkungan kerja Terhadap Kinerja Karyawan}

Lingkungan kerja berpengaruh signifikan terhadap kinerja karyawan dengan korelasi sebesar 0,698 atau memiliki hubungan yang kuat dengan kontribusi pengaruh sebesar 48,8\%. Pengujian hipotesis diperoleh nilai t hitung $>\mathrm{t}$ tabel atau $(7,492>$ $2,001)$. Dengan demikian hipotesis kedua yang diajukan bahwa terdapat berpengaruh signifikan antara lingkungan kerja terhadap kinerja karyawan diterima.

\section{Pengaruh Motivasi kerja dan Lingkungan kerja Terhadap Kinerja Karyawan}

Motivasi kerja dan lingkungan kerja berpengaruh signifikan terhadap kinerja karyawan dengan diperoleh persamaan regresi $\mathrm{Y}=7,031+0,378 \mathrm{X} 1+0,466 \mathrm{X} 2$, nilai korelasi sebesar 0,807 atau memiliki hubungan yang sangat kuat dengan kontribusi pengaruh sebesar $65,2 \%$ sedangkan sisanya sebesar $34,8 \%$ dipengaruhi faktor lain. Pengujian hipotesis diperoleh nilai $F$ hitung $>F$ tabel atau $(54,241>2,760)$. Dengan demikian hipotesis ketiga yang diajukan bahwa terdapat berpengaruh signifikan antara motivasi kerja dan lingkungan kerja terhadap kinerja karyawan diterima.

\section{KESIMPULAN DAN SARAN}

\section{Kesimpulan}

a. Motivasi kerja berpengaruh signifikan terhadap kinerja karyawan dengan kontribusi pengaruh sebesar 46,7\%. Uji hipotesis diperoleh nilai t hitung $>\mathrm{t}$ tabel atau $(7,190>$ $2,001)$.

b. Lingkungan kerja berpengaruh signifikan terhadap kinerja karyawan dengan kontribusi pengaruh sebesar 48,8\%. Uji hipotesis diperoleh nilai t hitung $>\mathrm{t}$ tabel atau $(7,492>2,001)$.

c. Motivasi kerja dan lingkungan kerja berpengaruh signifikan terhadap kinerja karyawan dengan kontribusi pengaruh sebesar $65,2 \%$ sedangkan sisanya sebesar $34,8 \%$ dipengaruhi faktor lain. Uji hipotesis diperoleh nilai $\mathrm{F}$ hitung $>\mathrm{F}$ tabel atau $(54,241>2,760)$.

\section{Saran}

a. Perusahaan harus mereview kembali besarnya pemberian gaji kepada karyawannya dengan mempertimbangkan kenaikan yang kiranya mampu memenuhi harapan karyawan dengan harapan mampu menambah semangat dalam bekerjanya.

b. Perusahaan harus mempertimbangkan renovasi ruangan kerja dengan membuat kedap suara mengingat lokasi kantor yang cukup bising dengan arus kendaraan sehingga tercipta suasana kerja yang cukup nyaman.

c. Kinerja karyawan pernyataan yang paling lemah adalah nomor 1 yaitu Perusahaan harus kembali melakukan pelatihan yang mengarah pada cara pelaksanaan pekerjaan 
yang mengacu pada urutan atau standar kerja yang telah ditetapkan oleh perusahaan sehingga karyawan mampu melakukan dengan baik sehingga kinerja dapat ditingkatkan lagi dengan maksimal.

\section{DAFTAR PUSTAKA}

Algifari (2015). Analisis Regresi untuk Bisnis dan Ekonomi. Yogyakarta: BPFE.

Andi Supangat (2015) Statistika dalam Kajian Deskriftif, Inferensi dan Non Parametic, Edisi Pertama, Jakarta: Kencana Prenada Media Group.

Arianto, N., \& Kurniawan, H. (2020). Pengaruh Motivasi dan Lingkungan Kerja Terhadap Kinerja Karyawan. JENIUS (Jurnal Ilmiah Manajemen Sumber Daya Manusia), 3(3), 312-321.

Damayanti, D., et al. (2021). Peran Work Overload, Work Environment, Work Family Conflict \& Work Stress Terhadap Job Performance. Jurnal Ilmiah Wahana Pendidikan, 7(3), 192-206.

Fransiska Deci Natalia, Umi Rusilowati (2013) Pengaruh Lingkungan Kerja Terhadap Kinerja Karyawan Pada PT. Bank Central Asia Cabang Cinere, Jurnal Kreatif Univeritas Pamulang, Vol.1 No.1, ISSN: 2339-0689.

Ghozali, I. 2013. Aplikasi Analisis Multivariate Dengan Program SPSS Edisi Ketujuh. Semarang : Badan Penerbit Universitas Diponegoro.

Gilford, J.P (1995), Tratis Creativity Dalam Anderson (2016) Creativity and Its Cultivation, John Wiley, New York.

Goklas, A., et al. (2021). Management Of Organizational Performance: The Role Of Human Resource Management Strategy. Jurnal Ad'ministrare, 8(1), 245-254.

Hasibuan, M. 2018. Manajeman Sumber Daya Manusia. Jakarta : PT Bumi Aksara.

Imam Ghozali (2017). Aplikasi Analisis Multivariate Dengan Program SPSS. Edisi Kelima. Semarang: Badan Penerbit Undip.

Istijanto (2016) Riset Sumber Daya Manusia. Jakarta: PT. Gramedia Pustaka

Jazuli Muktar (2019), Pengaruh Lingkungan Kerja Dan Motivasi Terhadap Kinerja Guru Pada Pondok Pesantren Asshiddiqiyah Jakarta, Jurnal Distrubsi Bisnis, Vol.1 No.3, ISSN: 2621-797X.

Komarudin (2018) Pengaruh Lingkungan Kerja Terhadap Kinerja Karyawan Pada PT. Pos Indonesia Dedpok, Jurnal Jenius Univeritas Pamulang, Vol.1 No.2, ISSN: 23390689.

Malholtra, Nares (2014), Basic Marketing Research. Pearson Education. England.

Mamesah, et al. 2018. Pengaruh Lingkungan Kerja, Disiplin Kerja, Dan Loyalitas Kerja Terhadap Kinerja Karyawan Pada LPP RRI Manado. Jurnal EMBA. Vol.4 No.3, Hal. 600-611.

Mangkunegara. AA. A. P. 2018. Manajeman Sumber Daya Manusia Perusahaan. Bandung : PT. Remaja Rosdakarya.

Mulyadi (2019), Pengaruh Lingkungan kerja dan Disiplin Kerja Terhadap Kinerja Guru SMAN 6 Kota Tangerang Selatan, Jurnal Ekonomi Efektif Universitas Pamulang, Vol.1 No.3, ISSN: 2622-8882

Nawawi. 2011. Manajeman Sumber Daya Manusia Untuk Bisnis yang Kompetitif. Yogyakarta : Gadjah Mada University Press.

Rawi, R. D. P., et al. (2018). Analisis Hubungan Motivasi Terhadap Kinerja Pegawai (Studi Kasus Pada Kantor Wali Kota Sorong Papua Barat). Manajemen Dewantara, 2(2), 87-94.

Retno Wulansasi (2020), Pengaruh Motivasi Terhadap Kinerja Karyawan Pada Hana Bank Kantor Pusat Jakarta, Jurnal Ekonomi Efektif Vol.3 No.1, ISSN: 2622-8882. 
Rivai, V dan Sagala, E. 2018. Manajeman Sumber Daya Manusia Untuk Perusahaan. Jakarta : PT. Rajawali Pers.

Sedarmayanti. 2019. Manajemen Sumber Daya Manusia. Bandung : PT Refika Aditama.

Singgih Santoso (2017). Menguasai Statistik Multivariat. Jakarta: PT Elex Media Komputindo.

Sri Mardiana (2020), Pengaruh Motivasi Terhadap Kinerja Pegawai Pada Kecamatan Ciputat Timur, Jurnal Kreatif Vol.8 No.2, ISSN: 2339-0689

Sudjana (2014) Penilaian Hasil Proses Belajar Mengajar, Bandung: PT. Remaja Rosdakarta.

Sugiyono. 2018. Metode Penelitian Kuantitatif, Kualitatif, dan R\&D. Bandung: Alfabeta.

Suharsimi Arikunto (2014). Prosedur Penelitian Suatu Pendekatan Praktek. Jakarta: Rineka Cipta.

Suhartanto (2016). Metode Riset Pemasaran. Bandung: Alfabeta

Suherman (2017), Petunjuk Praktir Untuk Melaksanakan Evaluasi Pendidikan Matematika, Bandung: Wijayakusumah.

Supardi, S. 2017. Kinerja Guru. Jakarta : PT. RajaGrafindo Press.

Sutrisno, E. 2019. Manajeman Sumber Daya Manusia. Edisi Pertama. Jakarta: PT. Kencana.

Suwanto, S., et al. (2021). Pengaruh Motivasi Dan Pengalaman Kerja Terhadap Produktivitas Karyawan Pada Happy Restaurant Di Bandung. Jurnal Ekonomi Efektif, 3(4), 546-554.

Wilson, B. 2012. Manajeman Sumber Daya Manusia. Erlangga. Jakarta. 